\title{
Biostimulant Application Improves Yield Parameters and Accentuates Fruit Color of Annurca Apples
}

\author{
Claudio Di-Vaio (D), Aurora Cirillo, Danilo Cice $(D)$, Christophe El-Nakhel * (D) and Youssef Rouphael $\mathbb{D}$ \\ Department of Agricultural Sciences, University of Naples Federico II, Via Universita 100, 80055 Portici, Italy; \\ claudio.divaio@unina.it (C.D.-V.); aurora.cirillo@unina.it (A.C.); danilo93mhr@hotmail.it (D.C.); \\ youssef.rouphael@unina.it (Y.R.) \\ * Correspondence: christophe.elnakhel@unina.it
}

Citation: Di-Vaio, C.; Cirillo, A.; Cice, D.; El-Nakhel, C.; Rouphael, Y. Biostimulant Application Improves Yield Parameters and Accentuates Fruit Color of Annurca Apples. Agronomy 2021, 11, 715. https:// doi.org/10.3390/agronomy11040715

Academic Editor: Enrique Eymar

Received: 23 March 2021

Accepted: 7 April 2021

Published: 9 April 2021

Publisher's Note: MDPI stays neutral with regard to jurisdictional claims in published maps and institutional affiliations.

Copyright: (c) 2021 by the authors. Licensee MDPI, Basel, Switzerland. This article is an open access article distributed under the terms and conditions of the Creative Commons Attribution (CC BY) license (https:/ / creativecommons.org/licenses/by/ $4.0 /)$

\begin{abstract}
The Annurca apple is a typical fruit from Southern Italy that is notable for its high firmness and characteristic flavor, and presents positive effects on human health. The aim of the present study was to improve the agronomic characteristics of Annurca trees and the quality of their fruits by the use of plant biostimulants. We performed the study with three biostimulants (protein hydrolysates, seaweed extracts, and microalgae) to determine their effects on trees and fruits at harvest and during fridge conservation. The measurements in the field concerned the production per plant, the number of fruits, the diameter and fruit weight, the diameter of trunk, the weight of pruning, the first harvest $\%$, and yield efficiency (plant prod./TCSA) for both growing seasons 2018-2019. The analyzed fruit parameters at harvest and during the fridge conservation were: flesh firmness, epicarp color, total soluble solids, $\mathrm{pH}$, and titratable acidity. The results showed positive effects of the biostimulants on the production and the color parameters, especially with microalgae enhancing fruit redness (5-fold) and color index (8.5-fold). In particular, protein hydrolysates and microalgae increased the production $(10.4 \%)$, diameter of the fruits $(7.0 \%)$, the first harvest percentage $(37.8 \%)$, and yield efficiency $(6.9 \%)$. The tested plant biostimulants showed no significant effect on the measured qualitative parameters. This study represents the first detailed research on the use of different types of biostimulants on Annurca trees and their impact on the quality of its fruits from harvest to storage, and may present a sustainable alternative for the "melaio" processes.
\end{abstract}

Keywords: Malus domestica; yield; fruit quality; color index; anthocyanin; post-harvest; cold storage; seaweed extracts; protein hydrolysates; micro algae

\section{Introduction}

The Annurca apple (Malus domestica Borkh.) is a typical cultivar cultivated in Southern Italy, especially in the region of Campania, where it represents $70 \%$ of the apple production [1]. The Annurca apple acquired the recognition of quality mark IGP (Protected Geographic Indication) by the European Union in the framework of the authentication and protection of characteristic agri-food products. This status promotes the marketing of this apple cultivar locally and internationally [2]. The fruit is medium-to-small sized with a flat shape, characterized by a thick skin, a quite firm flesh, an average juiciness; it is sweet but slightly acidic, with a modest aroma and good flavor characteristics [3].

Annurca fruits are not fully ripened at harvest; therefore, they undergo a particular reddening postharvest treatment using traditional structures called "melaio", which consist of a layer of straw on the soil supporting the fruits that are covered with shading nets to reduce incident solar radiation and temperature [4]. Several studies showed that the typical reddening treatment is likely responsible for the increase of bioactive compounds such as polyphenols, flavonoids, and anthocyanins during storage, hence conferring a strong antioxidant activity to Annurca fruits [2,5-7]. The polyphenolic compounds present in Annurca have shown positive effects on human health as presented by D'Angelo et al. [8]. Annurca polyphenolic extracts protect from the damage of gastric epithelia in vitro, and 
rat gastric mucosa in vivo [9]. Annurca apple cultivar displays anti-radical, hypolipidemic, and hypoglycemic activities, and it has been proven to reduce cell viability in colon cancer and HL-60 cell lines by activating apoptosis [9].

To solve the problem of Annurca cultivar redness, many reported studies in the literature showed the importance of biostimulants in improving the coloring efficiency of the fruit peel, reflecting the positive effect of protein hydrolysates and abscisic acid on the accumulation of anthocyanins in the "Red Globe" grapes [5]. Another problem of Annurca cultivation is the containment of plant vigor; therefore, clonal rootstocks are used to control the vegetative growth of apple trees. Nevertheless, dwarf rootstocks are poorly anchored and due to their shallow roots they are prone to nutrient deficiency and water stress. In order to plant at high densities and still take advantage of the strength of seedling rootstocks, vigor reduction can be achieved by grafting a dwarf interstem called interstock, between the scion and the rootstock [10-12]. To solve this problem, Di Vaio et al. [1] proposed the use of a combination of rootstocks (M9 or M27) on Annurca apple trees, including the dwarfing interstock on a vigorous rootstock that allows obtaining less vigorous and more productive trees than the ones grafted directly onto seedlings.

Biostimulants are new agro-ecological tools implemented to sustain the growth and profitability of the organic apple sector, especially in the management of organic horticultural systems [13]. Despite the large and increasing number of publications dealing with biostimulants [14], scientific-based information is still incomplete on their optimal use, crop specificity, and interaction with growing conditions. Studies on the effects of biostimulants on the growth and yield potential of plants have been conducted primarily on vegetable crops. Rouphael et al. [15] and Ertani et al. [16] demonstrated how protein hydrolysates were able to increase the plant productivity of vegetables.

In this study, we examined the effects of different biostimulants on the growth, yield, and fruit quality of cultivated apple trees belonging to the Annurca cultivar. For this purpose, we considered two consecutive growing seasons $(2018 / 2019)$ with the application of three different categories of biostimulants: protein hydrolysates, brown seaweed extracts, and microalgae extracts. In addition, their effect was also considered during the fruit cold storage period up to 120 days. Such findings could serve apple growers in the Campania region by reducing the additional costs of "melaio" processes.

\section{Materials and Methods}

\subsection{Experimental Site and Plant Material}

The experiment was conducted during the growing seasons 2018/2019 in Vitulazio (Caserta, Italy) $\left(41^{\circ} 9^{\prime} 54^{\prime \prime} 36 \mathrm{~N}, 14^{\circ} 13^{\prime} 04^{\prime \prime} 08 \mathrm{E}, 57 \mathrm{~m}\right.$ a.s.l.) at an apple orchard of the "Giaccio Frutta" Cooperative Society, on eight-year-old apple trees of standard Annurca cultivar grafted on M9 rootstock. The plants were trained to spindle training systems and spaced $4.5 \mathrm{~m}$ between the rows and $1.5 \mathrm{~m}$ within the rows, accounting for a planting density of 1481 trees/ha, and the cultivar "Sergente" was used as a pollinator.

\subsection{Experimental Design and Biostimulant Treatments}

The experimental setup consisted of a complete randomized block design and organized as reported by Graziani et al. [5]. Four treatments were compared:

(1) Plants were treated with only water as a control.

(2) Protein hydrolysates (PEP), Peptone 85/16 from A.I.CHEM company (Milan, Italy), a biostimulant authorized in organic farming and highly concentrated in amino acids. It was applied by foliar application at a dose of $150 \mathrm{~g} / 50 \mathrm{~L}$ of water.

(3) Seaweed mix (Ascophyllum nodosum and Laminaria digitate), a zinc-based formulation (ZINC 10 LG S), and a liquid potassium-based fertilizer (Red Skin LG). These products were mixed and used as foliar application. The overall treatment was called LG from Company L. Gobbi s.r.l. (Genova, Italy).

(4) Microalgae (MA), AgriAlgae Biologico Original from AgriAlgae ${ }^{\circledR}$ (Madrid, Spain), a high-quality organic biostimulant. 
All foliar biostimulant treatments were repeated four times during each growing season and carried out after the fruit setting phase at 20-day intervals.

\subsection{Biometric Analysis}

The measurements in the field concerned: (a) the equatorial diameter increase in the fruit (100 fruits per treatment); (b) the production (kg) per plant; (c) the number of fruits per plant; (d) the circumference of the trunk at $15 \mathrm{~cm}$ above the graft union, in order to determine the increase in the trunk cross sectional area (TCSA) calculated by standard formula $\left(\right.$ girth $\left.^{2} / 4 \pi\right)$; (e) the percentage of the first harvest (production $I^{\text {st }}$ harvest/total production $\times 100$ ); and $(\mathrm{f})$ the yield efficiency given by the ratio of production per plant and trunk cross sectional area (plant production/TCSA). The trunk circumference was measured at the beginning and at the end of the growing seasons of both years. Finally, in the winter phase, the pruning weight of 15 plants per treatment (five plants per block), was measured using an electronic dynamometer to evaluate the vegetative activity of the plants.

All fruits were harvested from 15 plants per treatment with homogeneous development and productive load that were grouped in three blocks of five plants each. The fruits were counted and weighed by an electronic dynamometer, then the average weight of the fruits was calculated. The fruits were then placed in a "melaio" to complete the reddening, and after about 15 days, they were placed in a cool room at a temperature of $3-4{ }^{\circ} \mathrm{C}$ for 120 days. All the measurements were conducted for two consecutive years.

\subsection{Physico-Chemical Analysis of Fruits}

The samples consisted of 40 fruits per treatment taken at four stages: (a) harvest; (b) after "melaio"; and after (c) 60 and (d) 120 days of refrigeration at $+2{ }^{\circ} \mathrm{C}$. The analyzed parameters were: fruit weight, firmness of the pulp, epicarp color, total soluble solids (TSS) content, $\mathrm{pH}$, and titratable acidity (TA).

The fruit weight was determined with an analytical balance, while the pulp firmness was determined with a manual penetrometer (Fruti Tester, Effegi, Milan, Italy) with an $8 \mathrm{~mm}$ tip on two opposite sides of the fruit. The TSS content was determined with a digital refractometer (Hanna instruments Inc., model HI 96814, Woonsocket, RI, USA), while the $\mathrm{pH}$ was determined with a $\mathrm{pH}$ meter (Crison Instruments, model GLP 21, Barcelona, Spain) and total acidity with an acid-base titration. The solution was titrated with $0.1 \mathrm{~N}$ sodium hydroxide standard solution. Fruit epicarp color was determined with a colorimeter (Minolta, model CR-400, Tokyo, Japan) measuring the parameters $\mathrm{L}^{*} \mathrm{a}^{*} \mathrm{~b}^{*}$ and calculating the color index $\mathrm{CI}=(1000 \times \mathrm{a}) /(\mathrm{b} \times \mathrm{L})$ in accordance with the work of Jimenez-Cuesta et al. [17]. The measurement was repeated on four points of the fruit: on two sides of the fruit exposed and shaded and two intermediate points.

\subsection{Statistical Analysis}

The data were subjected to analysis of variance (ANOVA), while mean separation was performed by Duncan's multiple range test $(p<0.05)$ and principal component analysis (PCA) was executed on biometric analysis, physico-chemical analysis, and colorimetric parameters using the statistical software SPSS for Windows (version 12.0.1, Chicago, IL, USA).

\section{Results and Discussion}

\subsection{Effect of Biostimulants on Biometric Parameters}

Our study aimed to determine the effects of the three different biostimulants (microalgae, protein hydrolysates, and seaweed extracts mixed with zinc and potassium) on the agronomic characteristics of apple trees and the physicochemical parameters of Annurca fruits. Figure 1 reports the diametrical increase in the fruits in both growing seasons and the moment of the first application of the biostimulants was indicated with time zero. At harvest in 2018 (Figure 1A), PEP and MA treatments showed a greater increase in the fruits' diameter compared to the control, with an increase of 27.08 and $26.52 \mathrm{~mm}$ with PEP and MA, respectively. In 2019 (Figure 1B), only MA reported a significant increase 
in fruit diameter compared to the control and the other treatments, with an increase of $24.7 \mathrm{~mm}$. Similar results have also been observed by Nagy et al. [18] where all algae product treatments significantly affected the apple fruit diameter, where the maximum increment was 30.5\% compared to the control. Additionally, Colavita et al. [19] showed the effect of seaweed extract on pear fruit, highlighting an average increase of $3 \%$ in diameter, $9 \%$ in weight, and $26 \%$ in the number of cells per area of parenchymatous tissue.

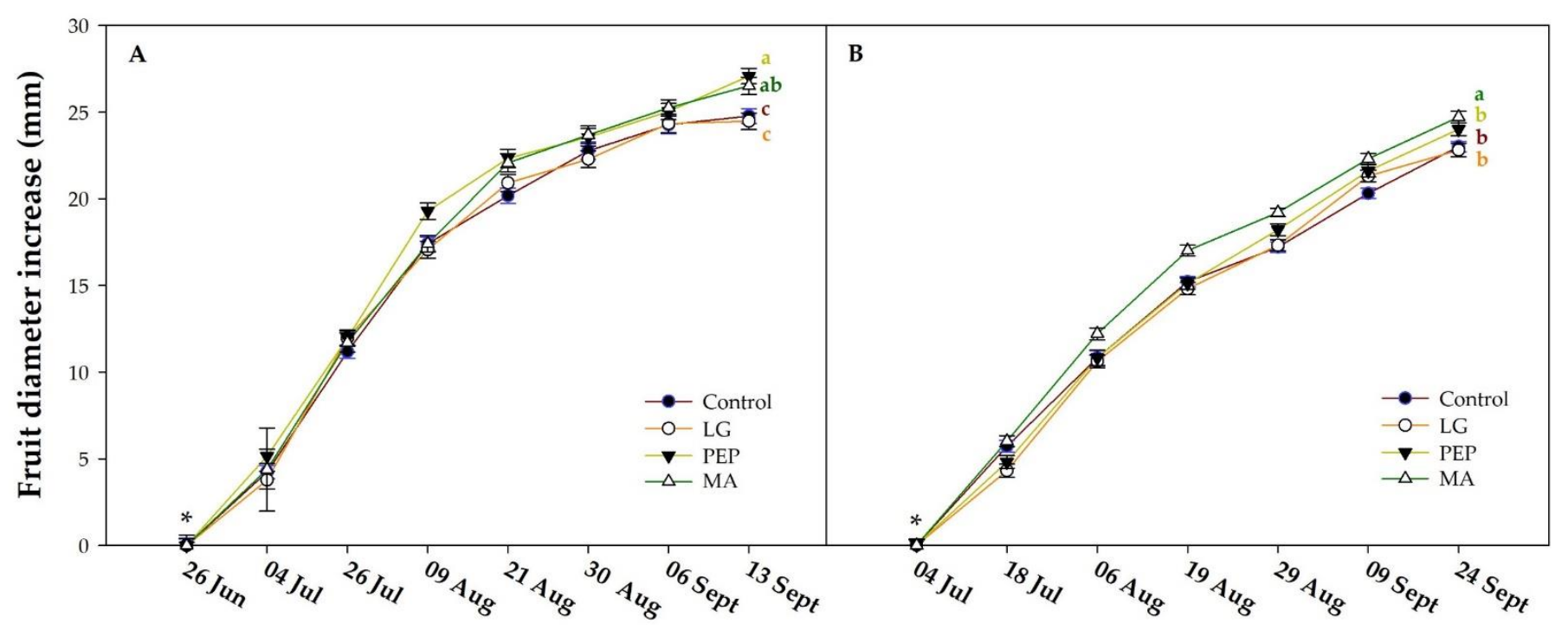

Figure 1. Effects of the biostimulants on the diametrical increase in the Annurca fruits during growing season 2018 (A) and 2019 (B). LG: seaweed mix + zinc + potassium; PEP: protein hydrolysates; and MA: microalgae. Vertical bars indicate \pm SE of the means; $\mathrm{n}=100$ fruits. Different letters $(\mathrm{a}, \mathrm{b}$, and $\mathrm{c})$ indicate significant differences according to Duncan's multiple-range test $(p=0.05)$, the letters have the same color of treatment curve. ${ }^{*}$ indicate the first application of the biostimulants.

Table 1 illustrates the effect of the biostimulants on the vegetative and productive parameters of trees. The application of protein hydrolysates induced significantly higher production of $15.0 \%$ per tree compared to the control. The production was the only parameter not influenced by the interaction between the growing season and the used biostimulants, whereas microalgae application induced intermediate results between PEP and the control. In addition, the application of MA improved fruit mean weight and the incidence of $\mathrm{I}^{\text {st }}$ harvest \% with an increase of 16.0 and of $47.0 \%$, respectively, in comparison to the control. The three biostimulants tested favored significant increases of trunk cross sectional area. Our results are consistent with those reported previously by Almadi et al. [20], who found that the trunks of field-grown trees treated with biostimulants were greater in diameter. Their results indicate the possibility of using amino acid-based biostimulants to promote the growth of young olive trees. Moreover, greater yield efficiency was shown with the application of MA and PEP with values of 1.56 and $1.54\left(\mathrm{~kg} / \mathrm{cm}^{2}\right)$, respectively, compared to that of the control $\left(1.45 \mathrm{~kg} / \mathrm{cm}^{2}\right)$. Previously, Abdul-Baki [21] observed that the improved yield generated by the protein hydrolyzates treatment has a significant value for the producer and could potentially be of much greater value during stress situations, especially in cases of extreme heat that negatively impact yield and fruit quality. Instead, Featonby-Smith and van Staden [22] determined that yield increase in seaweed-treated plants was associated with hormonal substances present in the extracts, especially cytokinins. In addition, pruning weight showed higher results with seaweed application, with $2.44 \mathrm{~kg}$ for LG and $2.48 \mathrm{~kg}$ for MA, which is in harmony with the results of Abou El-Yazied et al. [23]. These authors used seaweed extracts and significantly increased per plant the number of leaves, average leaf area, leaf and stem fresh weight, leaf and stem dry weight, and percentage of fruit set compared to the control. In addition, seaweed extracts enhance the uptake of nutrients and water by roots, hence generating better plant growth and vigor [24]. 
Table 1. Effect of biostimulants LG (seaweed mix + zinc + potassium), PEP (protein hydrolysates), and MA (microalgae) on production, fruit mean weight, $\mathrm{I}^{\text {st }}$ harvest percentage, trunk cross sectional area, yield efficiency, and pruning weight.

\begin{tabular}{|c|c|c|c|c|c|c|}
\hline Source of Variance & Production & $\begin{array}{l}\text { Fruit Mean } \\
\text { Weight }\end{array}$ & I $^{\text {st }}$ Harvest & $\begin{array}{c}\text { Trunk Cross } \\
\text { Sectional Area }\end{array}$ & $\begin{array}{c}\text { Yield } \\
\text { Efficiency }\end{array}$ & $\begin{array}{l}\text { Pruning } \\
\text { Weight }\end{array}$ \\
\hline & (kg/tree) & (g) & $(\%)$ & $\left(\mathrm{cm}^{2}\right)$ & $\left(\mathrm{kg} / \mathrm{cm}^{2}\right)$ & (kg) \\
\hline \multicolumn{7}{|l|}{ Biostimulants (B) } \\
\hline Control & $35.77 \pm 1.09 \mathrm{~b}$ & $118.68 \pm 4.48 \mathrm{~b}$ & $38.44 \pm 3.45 c$ & $24.62 \pm 0.22 c$ & $1.45 \pm 0.01 \mathrm{~b}$ & $1.94 \pm 0,17 \mathrm{~b}$ \\
\hline PEP & $41.12 \pm 1.97 \mathrm{a}$ & $123.34 \pm 3.21 b$ & $49.46 \pm 3.18 b$ & $26.52 \pm 0.24 b$ & $1.56 \pm 0.02 \mathrm{a}$ & $2.11 \pm 0.16 b$ \\
\hline LG & $35.25 \pm 1.27 \mathrm{~b}$ & $121.13 \pm 4.55 \mathrm{~b}$ & $41.05 \pm 3.78 c$ & $27.85 \pm 0.13 \mathrm{a}$ & $1.29 \pm 0.03 c$ & $2.44 \pm 0.18 \mathrm{a}$ \\
\hline MA & $37.87 \pm 1.92 \mathrm{ab}$ & $137.66 \pm 6.06 \mathrm{a}$ & $56.51 \pm 2.27 \mathrm{a}$ & $26.60 \pm 0.23 b$ & $1.54 \pm 0.01 \mathrm{a}$ & $2.48 \pm 0.15 \mathrm{a}$ \\
\hline \multicolumn{7}{|l|}{ Growing Season $(\mathrm{Y})$} \\
\hline 2018 & $37.01 \pm 1.18 \mathrm{a}$ & $144.55 \pm 2.49 \mathrm{a}$ & $34.99 \pm 2.36 b$ & $25.95 \pm 0.40 \mathrm{~b}$ & $1.49 \pm 0.02 \mathrm{a}$ & $1.39 \pm 0.05 b$ \\
\hline 2019 & $37.98 \pm 1.16 \mathrm{a}$ & $105.86 \pm 2.13 b$ & $57.74 \pm 1.39 \mathrm{a}$ & $26.85 \pm 0.56 a$ & $1.43 \pm 0.01 b$ & $3.06 \pm 0.08 \mathrm{a}$ \\
\hline $\mathrm{B}$ & * & $* * *$ & $* * *$ & $* * *$ & $* * *$ & $* * *$ \\
\hline Y & ns & $* * *$ & $* * *$ & * & * & $* * *$ \\
\hline $\mathrm{Y} \times \mathrm{B}$ & ns & $* * *$ & $* * *$ & $* *$ & $* *$ & $* *$ \\
\hline
\end{tabular}

All of the data are expressed as mean $\pm \mathrm{SE}, n=20 . \mathrm{ns},{ }^{*}, * *, * * *$ non-significant or significant at $p \leq 0.05,0.01$, and 0.001 , respectively. Different letters within each column indicate significant differences according to Duncan's multiple-range test $(p=0.05)$.

\subsection{Effect of Biostimulants and Exposure on Fruit Color}

As reported in Table 2, the studied factors (biostimulants, exposure of fruit, and the growing season) showed a significant interaction with all the studied parameters. The growing season $(Y)$ had only a significant effect $(p \leq 0.05)$ on the lightness $\left(L^{*}\right)$ of the Annurca fruits, where the growing season of 2019 exhibited an increase in fruit lightness of about $2.2 \%$. All the applied biostimulants provoked a significant amelioration in fruit color, such as a darker and more red color, lower $b^{*}$, and higher $\mathrm{CI}$. The highest effect was registered by MA, followed by PEP and then LG. In particular, the application of MA showed a greater red skin and, therefore, a higher value of $a^{*}$ (14.58); this was also observed in the color index (CI) where an 8.5-fold increase was shown for MA compared to the control. Moreover, the fruit exposure to the sun manifested significant differences in fruit color, where intermediate exposure and full sun meliorated the color. Higher values of $\mathrm{a}^{*}$ and $\mathrm{CI}$ were reported in the fruits exposed to the sun, contrary to $\mathrm{b}^{*}$ (responsible for the yellow $(+b)$ and blue $(-b)$ color), which showed the lowest value in this exposure. The shaded side of the apple fruit had lower xanthophyll cycle-dependent thermal dissipation and antioxidants of the ascorbate-glutathione pathway [25].

It was identically observed by Awad et al. [26] that the levels of anthocyanin, quercetin 3-glycosides, and total flavonoids were highest in fruits located on the top of the tree followed by fruit from the outer tree parts, whereas the lowest levels were found in fruits from the inner part of the tree. Apple fruit coloration is related to anthocyanin biosynthesis [27]. Soppelsa et al. [13] also determined that treatments with seaweed extract, B-group vitamins, and alfalfa protein hydrolysates were able to significantly improve the intensity and extension of the red coloration of apples at harvest. Correspondingly, the anthocyanin content in the skin of apples treated with the same biostimulants was significantly higher than that of the control, highlighting the potential influence of these substances on the synthesis of secondary metabolites in the apples. Nonetheless, Craigie [28] revealed that the red coloration of the fruit was either diminished or improved based on the cultivar. Moreover, as stated by Ertani et al. [29], the alfalfa plant-derived biostimulant stimulates nitrogen metabolism and the antioxidant system of the plant, and enhances phenylalanine ammonia-lyase (PAL) activity. Interestingly, the expression and activity of PAL is known to be correlated with the accumulation of anthocyanins in apples [30]. 
Table 2. Effect of biostimulants LG (seaweed mix + zinc + potassium), PEP (protein hydrolysates), and MA (micro algae) on the Annurca fruit color $\left(\mathrm{L}^{*} \mathrm{a}^{*} \mathrm{~b}^{*}\right.$ and color index (CI)) with different exposure at harvest. $\mathrm{L}^{*}$ indicates lightness, and $\mathrm{a}^{*}$ and $\mathrm{b}^{*}$ are color directions: $+\mathrm{a}^{*}$ is the red axis, $-\mathrm{a}^{\prime}$ is the green axis, $+b^{*}$ is the yellow axis and $-b^{*}$ is the blue axis.

\begin{tabular}{|c|c|c|c|c|}
\hline Source of Variance & $L^{*}$ & $a^{*}$ & $\mathbf{b}^{*}$ & CI \\
\hline \multicolumn{5}{|l|}{ Biostimulants (B) } \\
\hline Control & $64.46 \pm 0.73 a$ & $-2.92 \pm 1.29 \mathrm{~d}$ & $32.39 \pm 0.59 \mathrm{a}$ & $2.84 \pm 1.19 \mathrm{~d}$ \\
\hline PEP & $55.84 \pm 0.91 c$ & $10.20 \pm 1.30 \mathrm{~b}$ & $25.79 \pm 0.71 c$ & $16.22 \pm 1.79 \mathrm{~b}$ \\
\hline LG & $57.96 \pm 0.87 \mathrm{~b}$ & $4.25 \pm 1.29 c$ & $27.42 \pm 0.69 \mathrm{~b}$ & $10.68 \pm 1.67 c$ \\
\hline MA & $51.40 \pm 0.93 \mathrm{~d}$ & $14.58 \pm 1.19 \mathrm{a}$ & $22.59 \pm 0.67 \mathrm{~d}$ & $24.02 \pm 2.05 \mathrm{a}$ \\
\hline \multicolumn{5}{|l|}{ Exposure of fruit (E) } \\
\hline Shadow & $66.26 \pm 0.61 \mathrm{a}$ & $7.66 \pm 0.96 \mathrm{~b}$ & $34.21 \pm 0,52 \mathrm{a}$ & $-1.00 \pm 0.85 c$ \\
\hline Intermediate 1 & $59.40 \pm 0.75 b$ & $4.20 \pm 1.12 c$ & $28.07 \pm 0.60 \mathrm{~b}$ & $7.52 \pm 1.19 \mathrm{~b}$ \\
\hline Intermediate 2 & $58.04 \pm 0.86 b$ & $4.58 \pm 1.14 \mathrm{c}$ & $27.63 \pm 0.66 b$ & $9.41 \pm 1.56 \mathrm{~b}$ \\
\hline Sun & $45.97 \pm 0.71 \mathrm{c}$ & $24.98 \pm 0.76 \mathrm{a}$ & $18.28 \pm 0.46 c$ & $37.84 \pm 1.78 \mathrm{a}$ \\
\hline \multicolumn{5}{|l|}{ Growing season $(\mathrm{Y})$} \\
\hline 2018 & $56.80 \pm 0.69 b$ & $6.28 \pm 0,98 \mathrm{a}$ & $27.19 \pm 0.52 \mathrm{a}$ & $13.73 \pm 1.32 \mathrm{a}$ \\
\hline 2019 & $58.04 \pm 0.63 \mathrm{a}$ & $6.77 \pm 0.96 \mathrm{a}$ & $26.90 \pm 0.50 \mathrm{a}$ & $13.16 \pm 1.24 \mathrm{a}$ \\
\hline $\mathrm{B}$ & $* * *$ & $* * *$ & $* * *$ & $* * *$ \\
\hline E & $* * *$ & $* * *$ & $* * *$ & $* * *$ \\
\hline $\mathrm{Y}$ & * & ns & ns & ns \\
\hline $\mathrm{B} \times \mathrm{E} \times \mathrm{Y}$ & $* * *$ & $* * *$ & $*$ & $* *$ \\
\hline
\end{tabular}

All of the data are expressed as mean $\pm \mathrm{SE}, n=20 . \mathrm{ns},{ }^{*},{ }^{* *},{ }^{* * *}$ non-significant or significant at $p \leq 0.05,0.01$, and 0.001, respectively. Different letters within each column indicate significant differences according to Duncan's multiple-range test $(p=0.05)$.

\subsection{Effects of Biostimulants on Flesh Firmness, Total Soluble Solids Content, Total Acidity and Juice $\mathrm{pH}$}

The Annurca apple has very particular organoleptic properties, where its qualitative parameters and the effects of the different studied factors (biostimulants, time of storage and growing season) are listed in Table 3 . All the studied parameters showed a significant interaction between the factors $\mathrm{B} \times \mathrm{S} \times \mathrm{Y}$, except for the fruit firmness (Table 3). The firmness of the pulp represents a valid index for determining the degree of fruit ripeness in order to monitor the stage of the Annurca ripening at harvest and during post-harvest. The biostimulants had no significant differences with regard to the firmness, while significant differences were shown during the refrigerated storage at +60 and +120 days with an obvious reduction in the pulp firmness. Lo Scalzo et al. [3] observed that the decrease in the firmness of the Annurca apples after reddening could be due to an increase in large polymers in K oxalate-dimethylsulphoxide soluble pectins mainly composed of galacturonic acid, and also the decrease in low-molecular-weight fragments composed of glucose and rhamnose. The total soluble solids content (Table 3) showed similar values between the control, LG, and MA, while PEP reported a lower value of about $5.35 \%$ compared to the other treatments. Similar results have also been observed by Bradshaw et al. [31] and by De Sousa et al. [32], in which ANE (Ascophyllum nodosum extracts) treatment had no effect on fruit firmness, starch index at harvest, and soluble solids concentration. Whereas, in agreement with Robert and von Loeska [33], TSS showed an increase of $9.9 \%$ from the harvest to +120 days of cold storage, while in contrast to TSS, a reduction in titratable acidity of $49.3 \%$ was registered. Our results confirm Crouch's data [34], which reported a decline in titratable acidity in apple fruits after harvest. The decrease in TA was inversely correlated to the $\mathrm{pH}$, which increased by $28.2 \%$ at +120 days of cold storage compared to the control. Our results on the acidity reduction in the apples when treated with MA was consistent with the effects of seaweed extract on mango fruits, where a decreasing total acidity $\%$ was illustrated [24]. 
Table 3. Effects of biostimulants LG (seaweed mix + zinc + potassium), PEP (protein hydrolysates), and MA (microalgae) on flesh firmness, total soluble solids (TSS), titratable acidity (TA), and pH of the Annurca fruits at harvest, after reddening, and during the cold storage (+60 and +120 days).

\begin{tabular}{|c|c|c|c|c|}
\hline Source of Variance & Firmness $\left(\mathrm{kg} / \mathrm{cm}^{2}\right)$ & TSS $\left({ }^{\circ}\right.$ Brix $)$ & TA (g/L) & $\mathrm{pH}$ \\
\hline \multicolumn{5}{|l|}{ Biostimulants (B) } \\
\hline Control & $3.63 \pm 0.25 b$ & $12.67 \pm 0.21 \mathrm{a}$ & $6.38 \pm 0.40 \mathrm{a}$ & $3.67 \pm 0.10 a$ \\
\hline PEP & $3.65 \pm 0.12 b$ & $11.96 \pm 0.16 b$ & $\begin{array}{l}6.13 \pm \\
0.41 \mathrm{ab}\end{array}$ & $3.75 \pm 0.09 a$ \\
\hline LG & $3.69 \pm 0.08 \mathrm{ab}$ & $12.46 \pm 0.23 \mathrm{a}$ & $6.29 \pm 0.41 \mathrm{a}$ & $3.79 \pm 0.08 a$ \\
\hline MA & $3.85 \pm 0.12 \mathrm{a}$ & $12.67 \pm 0.25 a$ & $6.00 \pm 0.28 b$ & $3.75 \pm 0.09 a$ \\
\hline \multicolumn{5}{|l|}{ Time of storage (S) } \\
\hline Harvest & $5.49 \pm 0.10 \mathrm{a}$ & $11.83 \pm 0.14 \mathrm{~d}$ & $9.04 \pm 0,19 \mathrm{a}$ & $3.12 \pm 0.07 c$ \\
\hline After reddening & $3.29 \pm 0.10 b$ & $12.25 \pm 0.28 \mathrm{c}$ & $5.58 \pm 0,13 b$ & $3.96 \pm 0.04 b$ \\
\hline+60 & $3.01 \pm 0.07 c$ & $12.67 \pm 0.21 b$ & $5.58 \pm 0.10 b$ & $3.88 \pm 0.07 \mathrm{~b}$ \\
\hline+120 & $3.03 \pm 0.08 c$ & $13.00 \pm 0.25 \mathrm{a}$ & $4.58 \pm 0.16 c$ & $4.00 \pm 0.00 \mathrm{a}$ \\
\hline \multicolumn{5}{|l|}{ Growing season (Y) } \\
\hline 2018 & $4.00 \pm 0.16 \mathrm{a}$ & $12.96 \pm 0.14 \mathrm{a}$ & $5.88 \pm 0.28 b$ & $3.73 \pm 0.45 a$ \\
\hline 2019 & $3.41 \pm 0.16 b$ & $11.92 \pm 0.14 b$ & $6.52 \pm 0.24 \mathrm{a}$ & $3.75 \pm 0.44 a$ \\
\hline B & * & $* * *$ & * & ns \\
\hline S & $* * *$ & $* * *$ & $* * *$ & $* * *$ \\
\hline $\mathrm{Y}$ & $* * *$ & $* * *$ & $* * *$ & ns \\
\hline $\mathrm{B} \times \mathrm{S} \times \mathrm{Y}$ & ns & $* * *$ & $* * *$ & $* * *$ \\
\hline
\end{tabular}

All of the data are expressed as mean $\pm \mathrm{SE}, n=20 . \mathrm{ns},{ }^{*},{ }^{* * *}$ non-significant or significant at $p \leq 0.05$ and 0.001 , respectively. Different letters within each column indicate significant differences according to Duncan's multiple-range test $(p=0.05)$.

\subsection{Principal Component Analysis (PCA)}

A principal component analysis (PCA) was conducted to highlight the effects of the biostimulant treatments on all the parameters analyzed above. The first two principal components (PCs) explained $81.01 \%$ of the cumulative variance (Figure 2), with PC1 accounting for $54.8 \%$ and PC2 for $26.2 \%$. The PC1 was positively correlated with fruit mean weight, $\mathrm{I}^{\text {st }}$ harvest $\%$, and CI, and negatively correlated with TA and fruit firmness. Moreover, PC2 was positively correlated with production and yield efficiency, while negatively correlated with TCSA, pruning weight, TSS, and PH. PCA is effective in plotting the physico-chemical and biometric parameters of the Annurca apple trees in relation to the different biostimulant treatments and their usefulness. In particular, the protein hydrolysates (PEP) treatment was positioned in the upper right quadrant of the PCA score plot as it delivered high production, yield efficiency, $\mathrm{I}^{\text {st }}$ harvest percentage, and CI. The MA treatment, positioned between the right quadrants, delivered high pruning weight and trunk cross sectional area (TCSA). 


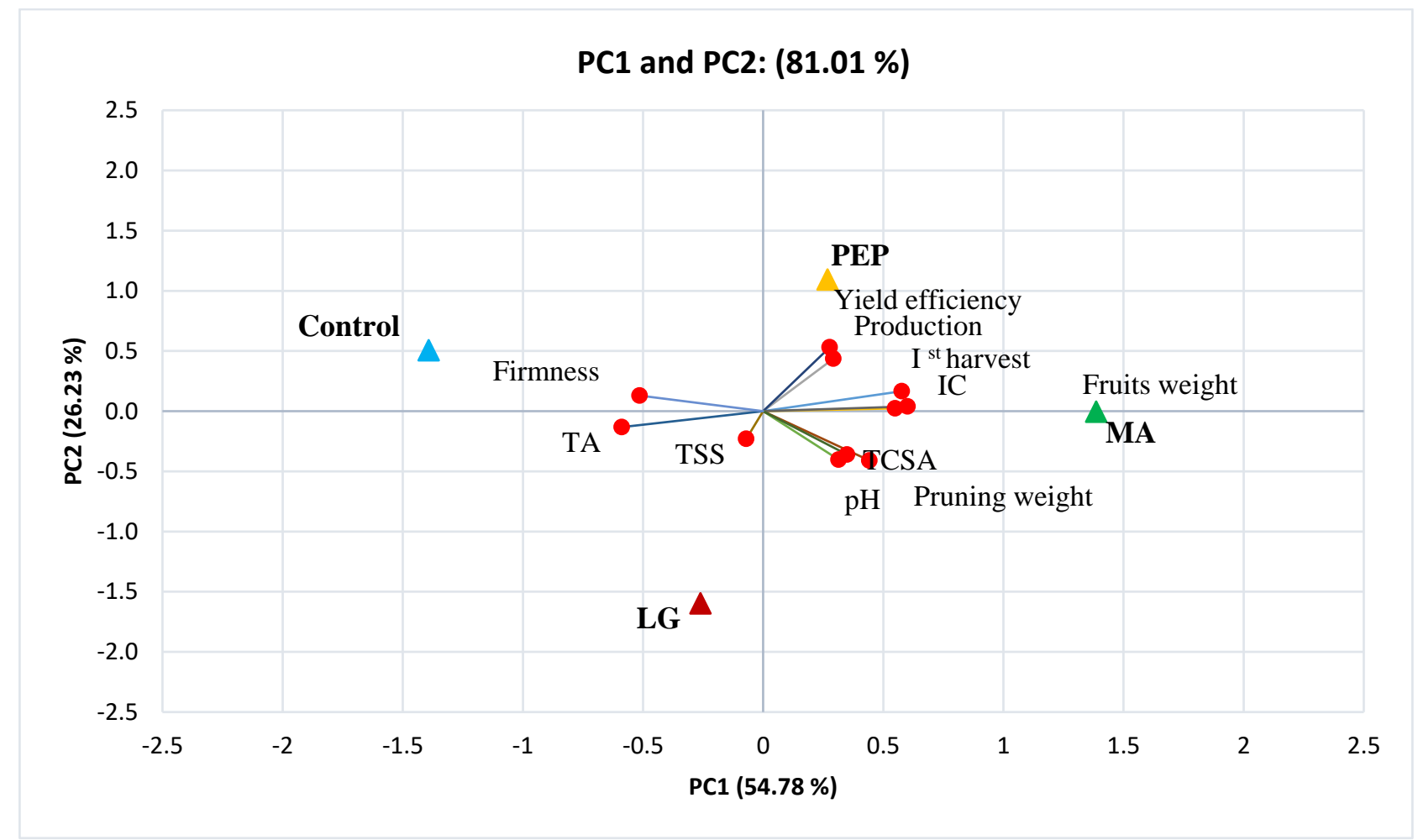

Figure 2. Principal component analysis (PCA) based on the biostimulant treatments with respect to production, fruits weight, pruning weight, $\mathrm{I}^{\text {st }}$ harvest, trunk cross sectional area (TCSA), yield efficiency, total soluble solids (TSS), titratable acidity (TA), $\mathrm{pH}$, firmness, and color index (CI).

\section{Conclusions}

This study emphasizes on the importance of biostimulants in enhancing fruit color and production parameters of Annurca apple trees. In particular, biostimulants based on protein hydrolysates and microalgae can be used to increase Annurca production $(10.41 \%)$, the diameter of the fruits, the first harvest percentage $(37.84 \%)$, and the yield efficiency $(6.9 \%)$. Macroalgae products favored an increase in the trunk cross sectional area, while seaweed-based products improved the vegetative activity of plant. Biostimulant application had no significant effects on the quality fruit parameters (firmness, TSS, AT and $\mathrm{pH}$ ); on the contrary, cold storage influenced fruit quality, showing an increase in TSS and a reduction in TA, which are important parameters for the apple fruit quality. This study represents one of the first detailed research endeavor into the impact of different types of biostimulants on Annurca apple quality at harvest and during storage and can present a sustainable alternative to "melaio" processes.

Author Contributions: Conceptualization, C.D.-V. and Y.R.; methodology, C.D.-V.; software, A.C.; validation, C.E.-N., A.C., and D.C.; formal analysis, C.D.-V.; investigation, A.C. and D.C.; resources, Y.R. and C.D.-V.; data curation, A.C. and C.D.-V.; writing-original draft preparation, A.C. and C.D.-V.; writing-review and editing, C.E.-N. and C.D.-V.; visualization, A.C.; supervision, Y.R. and C.D.-V.; project administration, C.D.-V. and Y.R.; funding acquisition, Y.R. and C.D.-V. All authors have read and agreed to the published version of the manuscript.

Funding: This research was funded by PSR Campania 2014/2020 Research Project Measure 10 Type of Intervention 10.2.1 - Conservation of indigenous genetic resources to protect biodiversity Vegetable Genetic Resources-CUP: B24I19000440009.

Institutional Review Board Statement: Not applicable.

Informed Consent Statement: Not applicable. 
Data Availability Statement: The datasets generated for this study are available on request to the corresponding author.

Acknowledgments: We are grateful to the agricultural cooperative "Giaccio Frutta"-Vitulazio (CE), which hosted the trial. We would like to thank also the AgriAlgae ${ }^{\circledR}$, A.I.CHEM, and L. Gobbi Companies for providing the biostimulants tested.

Conflicts of Interest: The authors declare no conflict of interest.

\section{References}

1. Di Vaio, C.; Cirillo, C.; Buccheri, M.; Limongelli, F. Effect of interstock (M.9 and M.27) on vegetative growth and yield of apple trees (cv “Annurca"). Sci. Hortic. 2009, 119, 270-274. [CrossRef]

2. D'Abrosca, B.; Fiorentino, A.; Monaco, P.; Oriano, P.; Pacifico, S. Annurcoic acid: A new antioxidant ursane triterpene from fruits of cv. Annurca apple. Food Chem. 2006, 98, 285-290. [CrossRef]

3. Lo Scalzo, R.; Testoni, A.; Genna, A. "Annurca” apple fruit, a southern Italy apple cultivar: Textural properties and aroma composition. Food Chem. 2001, 73, 333-343. [CrossRef]

4. Petriccione, M.; Raffone, E.; Rega, P. Post-harvest of the Annurca apples in Campania region. Studies by the Istituto Sperimentale per la Frutticoltura [Malus pumila L.]. Italus Hortus 2004, 11, 52-54.

5. Graziani, G.; Ritieni, A.; Cirillo, A.; Cice, D.; Di Vaio, C. Effects of biostimulants on annurca fruit quality and potential nutraceutical compounds at harvest and during storage. Plants 2020, 9, 775. [CrossRef]

6. Cefarelli, G.; D'Abrosca, B.; Fiorentino, A.; Izzo, A.; Mastellone, C.; Pacifico, S.; Piscopo, V. Free-radical-scavenging and antioxidant activities of secondary metabolites from reddened cv. Annurca apple fruits. J. Agric. Food Chem. 2006, 54, 803-809. [CrossRef]

7. Napolitano, A.; Cascone, A.; Graziani, G.; Ferracane, R.; Scalfi, L.; Di Vaio, C.; Ritieni, A.; Fogliano, V. Influence of variety and storage on the polyphenol composition of apple flesh. J. Agric. Food Chem. 2004, 52, 6526-6531. [CrossRef] [PubMed]

8. D'Angelo, S.; Sammartino, D. Protective Effect of Annurca Apple Extract Against Oxidative Damage in Human Erythrocytes. Curr. Nutr. Food Sci. 2015, 11, 248-256. [CrossRef]

9. Graziani, G.; D’Argenio, G.; Tuccillo, C.; Loguercio, C.; Ritieni, A.; Morisco, F.; Del Vecchio Blanco, C.; Fogliano, V.; Romano, M. Apple polyphenol extracts prevent damage to human gastric epithelial cells in vitro and to rat gastric mucosa in vivo. Gut 2005, 54, 193-200. [CrossRef] [PubMed]

10. Vercammen, J.; Van Daele, G.; Gomand, A. Can fruit size and colouring of "jonagold" be improved by a different rootstock? Acta Hortic. 2007, 732, 159-163. [CrossRef]

11. Samad, A.; McNeil, D.L.; Khan, Z.U. Effect of interstock bridge grafting (M9 dwarfing rootstock and same cultivar cutting) on vegetative growth, reproductive growth and carbohydrate composition of mature apple trees. Sci. Hortic. 1999, 79, 23-38. [CrossRef]

12. Webster, A.D. Rootstock and interstock effects on deciduous fruit tree vigour, precocity, and yield productivity. N. Z. J. Crop Hortic. Sci. 1995, 23, 373-382. [CrossRef]

13. Soppelsa, S.; Kelderer, M.; Casera, C.; Bassi, M.; Robatscher, P.; Andreotti, C. Use of biostimulants for organic apple production: Effects on tree growth, yield, and fruit quality at harvest and during storage. Front. Plant Sci. 2018, 9, 1342. [CrossRef] [PubMed]

14. Colla, G.; Rouphael, Y. Biostimulants in horticulture. Sci. Hortic. 2015, 196, 1-2. [CrossRef]

15. Rouphael, Y.; Colla, G.; Giordano, M.; El-Nakhel, C.; Kyriacou, M.C.; De Pascale, S. Foliar applications of a legume-derived protein hydrolysate elicit dose-dependent increases of growth, leaf mineral composition, yield and fruit quality in two greenhouse tomato cultivars. Sci. Hortic. 2017, 226, 353-360. [CrossRef]

16. Ertani, A.; Sambo, P.; Nicoletto, C.; Santagata, S.; Schiavon, M.; Nardi, S. The use of organic biostimulants in hot pepper plants to help low input sustainable agriculture. Chem. Biol. Technol. Agric. 2015, 2, 1-10. [CrossRef]

17. Jiménez, M.; Cuquerella, J.; Martínez, J. Determination of a color index for citrus fruit degreening. In Proceedings of the International Society of Citriculture, Shimizu, Japan, 9-12 November 1981; Volume 2, pp. 750-753.

18. Nagy, P.T.; Csihon, Á.; Szabó, A. Effects of Algae Products on Nutrient Uptake and Fruit Quality of Apple. Nat. Resour. Sustain. Dev. 2019, 9, 80-91. [CrossRef]

19. Colavita, G.M.; Spera, N.; Blackhall, V.; Sepulveda, G.M. Effect of seaweed extract on pear fruit quality and yield. Acta Hortic. 2011, 909, 601-608. [CrossRef]

20. Almadi, L.; Paoletti, A.; Cinosi, N.; Daher, E.; Rosati, A.; Di Vaio, C.; Famiani, F. A biostimulant based on protein hydrolysates promotes the growth of young olive trees. Agriculture 2020, 10, 618. [CrossRef]

21. Abdul-Baki, A.A. Tolerance of Tomato Cultivars and Selected Germplasm to Heat Stress. J. Am. Soc. Hortic. Sci. 1991, 116, 1113-1116. [CrossRef]

22. Featonby-Smith, B.C.; Van Staden, J. The Effect of Seaweed Concentrate and Fertilizer on the Growth of Beta vulgaris. Z. Pflanzenphysiol. 1983, 112, 155-162. [CrossRef]

23. Abou El-Yazied, A.; El-Gizawy, A.M.; Ragab, M.I.; Hamed, E.S. Effect of Seaweed Extract and Compost Treatments on Growth, Yield and Quality of Snap Bean. J. Am. Sci. 2012, 8, 1-20. 
24. Mohamed, A.Y.; El-Sehrawy, O.A.M. Effect of seaweed extract on fruiting of Hindy Bisinnara mango trees. J. Am. Sci. 2013, 9, 537-544.

25. Ma, F.; Cheng, L. The sun-exposed peel of apple fruit has higher xanthophyll cycle-dependent thermal dissipation and antioxidants of the ascorbate-glutathione pathway than the shaded peel. Plant Sci. 2003, 165, 819-827. [CrossRef]

26. Awad, M.A.; De Jager, A. Flavonoid and chlorogenic acid concentrations in skin of "Jonagold" and "Elstar" apples during and after regular and ultra low oxygen storage. Postharvest Biol. Technol. 2000, 20, 15-24. [CrossRef]

27. Honda, C.; Kotoda, N.; Wada, M.; Kondo, S.; Kobayashi, S.; Soejima, J.; Zhang, Z.; Tsuda, T.; Moriguchi, T. Anthocyanin biosynthetic genes are coordinately expressed during red coloration in apple skin. Plant Physiol. Biochem. 2002, 40, 955-962. [CrossRef]

28. Craigie, J.S. Seaweed extract stimuli in plant science and agriculture. J. Appl. Phycol. 2011, 23, 371-393. [CrossRef]

29. Ertani, A.; Schiavon, M.; Muscolo, A.; Nardi, S. Alfalfa plant-derived biostimulant stimulate short-term growth of salt stressed Zea mays L. plants. Plant Soil 2013, 364, 145-158. [CrossRef]

30. Liu, Y.; Che, F.; Wang, L.; Meng, R.; Zhang, X.; Zhao, Z. Fruit coloration and anthocyanin biosynthesis after bag removal in non-red and red apples (Malus $\times$ domestica Borkh.). Molecules 2013, 18, 1549-1563. [CrossRef] [PubMed]

31. Bradshaw, T.L.; Berkett, L.P.; Griffith, M.C.; Kingsley-Richards, S.L.; Moran, R.E.; Darby, H.M.; Garcia, M.E.; Parsons, R.L. Assessment of kelp extract biostimulants on disease incidence and damage in a certified organic apple orchard. Acta Hortic. 2013, 1001, 265-272. [CrossRef]

32. De Sousa, A.M.; Ayub, R.A.; Viencz, T.; Botelho, R.V. Fruit set and yield of apple trees cv. Gala treated with seaweed extract of Ascophyllum nodosum and thidiazuron. Rev. Bras. Frutic. 2019, 41. [CrossRef]

33. Robert, S.; Von Loeska, H. Effect of Harvesting and Handling Percentage on Composition of Unprocessed foods. In Nutritional Evaluation of Food Processing; John-Willey \& Sons Inc.: New York, NY, USA, 1960; p. 76.

34. Crouch, I. 1-methylcyclopropene (SmartFresh ${ }^{\mathrm{TM}}$ ) as an alternative to modified atmosphere and controlled atmosphere storage of apples and pears. Acta Hortic. 2003, 600, 433-440. [CrossRef] 